\title{
Distribution and Abundance of Larval Burbot and Deepwater Sculpin in Lake Michigan
}

\author{
Pamela J. Mansfield and David J. Jude \\ Great Lakes Research Division, Institute of Science and Technology \\ University of Michigan, Ann Arbor, Michigan 48109 \\ David T. Michaud \\ Wisconsin Electric Power Company \\ Post Office Box 2046, Milwaukee, Wisconsin 53201 \\ Dan C. Brazo \\ Department of Fisheries and Wildlife \\ Michigan State University, East Lansing, Michigan 48824 \\ John Gulvas \\ Consumers Power Company \\ 1945 Parnall Road, Jackson, Michigan 49201
}

\begin{abstract}
Samples from seven locations at depths to $21 \mathrm{~m}$, collected over periods of up to 8 years, were used to describe the nearshore distribution and abundance of burbot Lota lota and deepwater sculpin Myoxocephalus thompsoni larvae in Lake Michigan. Based upon power-plant-entrainment samples and field collections, burbot larvae $(3.0-7.5 \mathrm{~mm})$ occurred from late March to mid-June, most abundantly in April and May, and most often at water temperatures of 6-12 C. Larvae were collected from the 0.5 - to $13.5-\mathrm{m}$ depth strata as far lakeward as the $21 \mathrm{-m}$ bottom contour, the limit of offshore sampling. In eastern Lake Michigan, highest densities (up to 843 larvae/ $1,000 \mathrm{~m}^{3}$ ) were at the 1 - $\mathrm{m}$ contour; in Green Bay, up to 24,000 larvae $/ 1,000 \mathrm{~m}^{3}$ were detected near the Bark River. High densities of burbot larvae at bottom depths $3 \mathrm{~m}$ and less indicated inshore spawning and river spawning at some sites. Deepwater sculpin larvae first occurred in early February and were common in March and April entrainment samples. Larvae (8.0-22.0 $\mathrm{mm}$ ) were in nearshore waters usually through May at depth strata of 0.5 to $17 \mathrm{~m}$ as far lakeward as the 18-m bottom contour. Most larvae occurred at water temperatures below $6 \mathrm{C}$. Field densities were low, 5 to 78 larvae $/ 1,000 \mathrm{~m}^{3}$. Deepwater sculpin larvae were pelagic and were dispersed over great distances by currents.
\end{abstract}

Received July 12, 1982

Accepted December 17, 1982

Studies of the distribution and abundance of larval fishes, in combination with size or age data, can provide insight into habitat requirements of early-life stages, extent of early mortality, and dispersal mechanisms. In addition, such data can be used to infer spawning time and habitat, particularly when high densities of larvae are found. Such evidence is especially important for Lake Michigan, where winter conditions have hampered life-history observations on certain species. In this paper, we summarize our Lake Michigan data for larvae of burbot Lota lota and deepwater sculpin $M y$ oxocephalus thompsoni, collected over 8 years of research in connection with power-plant-impact assessments.

Burbot has a wide geographical distribution. Adults occur primarily in deep waters of lakes (Scott and Crossman 1973). Burbot were caught at all depths in bottom nets fished during June through October from 13 to $34 \mathrm{~m}$ in northeastern Lake Michigan and were most concentrated from 13 to 21 and 31 to $34 \mathrm{~m}$ (Van Oosten et al. 1946). Studies of burbot in Lake of the Woods, Minnesota (Muth 1973), Lake Simcoe, Ontario (McCrimmon 1959), Oneida Lake, New York (Clady 1976), and southwestern Lake Superior (Bailey 1972) indicate probable winter 
spawning over rubble or sand bottoms, usually on shoals or reefs. Presence of burbot in Great Lakes tributary streams during winter (our data) suggests that the species also may spawn in streams.

Adults and larvae of deepwater sculpin are primarily inhabitants of the deeper water $(>50$ m) of Lake Michigan (Deason 1939; Wells 1968). Adults are bottom dwellers, but our data show larvae may inhabit any stratum. The deepwater sculpin and the fourhorn sculpin Myoxocephalus quadricornis once were considered subspecies, but now are believed to be distinct species (Robins et al. 1980) based on morphological characters (McAllister et al. 1978). Deepwater sculpin populations declined in Lake Michigan during the 1960s (Wells and McLain 1972), but made a striking comeback in the 1970s (L. Wells, Great Lakes Fishery Laboratory, personal communication). Adult deepwater sculpin have been collected in Lake Superior as shallow as about 73 $m$ and as deep as $366 \mathrm{~m}$ (Dryer 1966), and are thought to spawn from late November to midMay (J. H. Selgeby, United States Fish and Wildlife Service, personal communication). Khan and Faber (1974) believe deepwater sculpin in the Great Lakes spawn throughout winter, spring, and early summer due to isothermal conditions in the profundal zones of the lakes inhabited. Day length or intensity of light often controls spawning time in fish, but deepwater sculpin may be unable to detect light at the depths they inhabit, so may not spawn synchronously (C. Kraft, Wisconsin Sea Grant, personal communication). (The amphipod Pontoporeia affinis offers a precedent; it generally breeds in winter, but deeper than $100 \mathrm{~m}$, it also breeds outside the cold season, probably because of darkness: Segerstråle 1970.) Most evidence for deepwater sculpin spawning time and place is circumstantial because direct observation, or collection, of spawning adults is difficult at these depths.

Here, we address the inshore distribution of larval deepwater sculpin and burbot in Lake Michigan, and infer spawning habits and times for these species. Areas sampled were sites of proposed or existing power plants, and all stations fell within the 21-m lake-bottom contour. Despite this spatial limitation, the data support some generalizations and hypotheses about the early life history of the two species. Power-plantentrainment samples collected during January through March permitted detection of larvae when field sampling was not possible.

\section{Study Area}

The eastern shore of Lake Michigan consists of sand interspersed with occasional rock and clay outcroppings (Liston et al. 1981). Four Michigan electricity-generating plants (sites of data collection) are located on this shore: the D. C. Cook nuclear plant near Bridgman, the Palisades nuclear plant near South Haven, the J. H. Campbell fossil-fuel plant near Grand Haven, and the Ludington pumped-storage plant near Ludington (Fig. 1). On the western shore, data were collected at the Haven site $11 \mathrm{~km}$ north of Sheboygan, which has a rocky, fairly regular bottom, and at the Ozaukee site north of Port Washington, where the bottom is sandy and featureless. Data also were collected in northern Green Bay, southwest of Escanaba. This area includes wide shoals of rock and sand adjacent to a more steeply sloping rocky area.

\section{Methods}

At all sites except Ludington, larvae were sampled with conical nylon plankton nets of $0.5-\mathrm{m}$ diameter and 335- to $363-\mu \mathrm{m}$ mesh, equipped with flowmeters; at Ludington, 1-mdiameter nets were used. Samples were preserved with $10 \%$ formaldehyde solution (for details see Jude et al. 1979, 1980, 1981; WAPORA 1979; Liston et al. 1981).

At most sites two transects perpendicular to shore were established, one at the plant site, and one at a reference area. Exceptions were Ludington (four transects), Escanaba (five), and Haven (three) (Fig. 1). At Escanaba, in particular, complex bottom topography, shoals, and diverse substrates required that more transects be established. At all sites except Escanaba, burbot and deepwater sculpin larvae were similar in abundance between or among transects. At Escanaba, data were analyzed separately by transect due to extreme abundance differences.

Stations were established at certain depth contours along each transect to assess plant effects (Table 1). Samples from the 1-m Cook, Palisades, and Campbell stations were collected by waders who pulled the net for $61 \mathrm{~m}$. All other samples came from 5-minute tows behind a boat run parallel to shore. At Palisades, Campbell, and Ludington, in addition to midwater and surface tows, nets were mounted on 


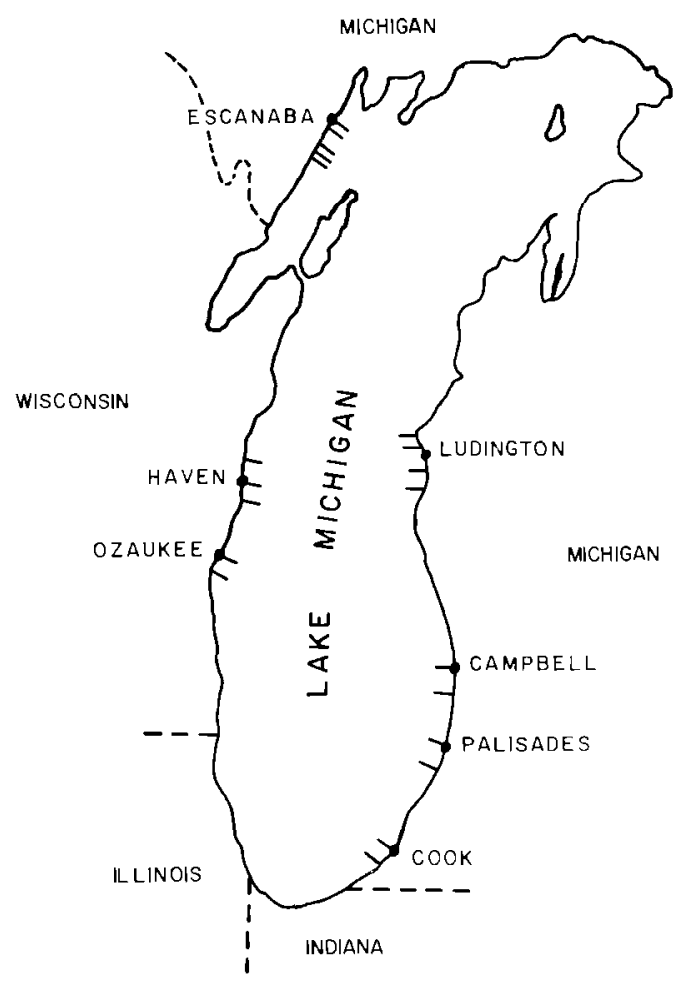

FIGURE 1.-Location of seven sites on Lake Michigan where larval fish were collected during 1973-1980. Lines extending from shore indicate sampling transects (not to scale).

aluminum epibenthic sleds and towed along the bottom. At most sites, discrete depth strata were sampled at each station by means of horizontal tows; samples undoubtedly were slightly con- taminated by larvae higher in the water column when nets were retrieved. Depth was controlled by tow-rope angle and length; error was generally $0.5 \mathrm{~m}$ or less. At Ludington, stepped, oblique tows were performed. Data from Escanaba and Palisades were pooled across depth strata in order to simplify analyses of dispersion and density trends.

Field sampling began in April at all sites and continued into autumn; it covered $1-8$ years at various sites (Table 1). All sites were sampled during 1978, providing a basis for seasonal comparisons among sites independently of annual variation.

Power-plant-entrainment samples were collected at the eastern sites (Table 1). At Campbell, $363-\mu \mathrm{m}$-mesh nets were deployed at the plant discharge (Jude et al. 1980). At Ludington, 1-m-diameter plankton nets were towed between the jetties in Lake Michigan in front of the power plant intakes (Liston et al. 1981). Samples at Cook were taken from the intake and discharge forebays with diaphragm pumps (Jude et al. 1979). At Palisades, submersible pumps drew water from the forebay (WAPORA 1979). At the latter sites, pumped water was filtered through plankton nets suspended in drums.

Preserved fish larvae and eggs were sorted, identified, and counted with the aid of dissecting microscopes or hand lenses. Larvae were measured (total length, TL) to the nearest 0.5 $\mathrm{mm}$. We used Fish (1932), Khan and Faber (1974), Lippson and Moran (1974), Dorr et al. (1976), and Wang and Kernehan (1979) for

TABLE 1.-Sampling history for larval burbot and deepwater sculpin in Lake Michigan.

\begin{tabular}{|c|c|c|c|c|c|}
\hline $\begin{array}{c}\text { Site } \\
\text { (Fig. 1) }\end{array}$ & $\begin{array}{l}\text { Number } \\
\text { of } \\
\text { transects }\end{array}$ & Stations (depth contours, m) & $\begin{array}{c}\text { Year(s) } \\
\text { sampled }\end{array}$ & $\begin{array}{c}\text { Field } \\
\text { samples }\end{array}$ & $\begin{array}{l}\text { Power-plant- } \\
\text { entrainment } \\
\text { samples }\end{array}$ \\
\hline \multicolumn{6}{|c|}{ East shore } \\
\hline Cook & 2 & $1,6,9,21$ & $1973-1980$ & Apr-Sep & Jan-Dec \\
\hline Palisades & 2 & $1,3,6,9,12,15$ & 1978 & Apr-Oct & Apr-Oct \\
\hline Campbell & 2 & $1,1.5,3,6,9,12,15,18^{\mathrm{a}}, 21^{\mathrm{a}}$ & $1977-1980$ & Apr-Sep & Jan-Dec \\
\hline Ludington & 4 & $1.5,3,6,9,12^{b}$ & $1978-1979$ & Apr-Oct & Apr-Oct \\
\hline \multicolumn{6}{|c|}{ West shore } \\
\hline Ozaukee & 2 & $6,9,12$ & 1978 & Apr-Sep & None \\
\hline Haven & 3 & $3,6,9,12$ & 1978 & Apr-Sep & None \\
\hline Escanaba & 5 & & 1978 & Apr-Nov & None \\
\hline On shoals & 2 & $1.5,3,6$ & & & \\
\hline Off shoals & 3 & $1.5,3,6,9$ & & & \\
\hline
\end{tabular}

${ }^{\text {a }}$ Samples were taken at these stations only during June to September 1977

D Samples were taken at this station only during 1979. 
TABLE 2.-Summary of collection statistics for larval burbot and deepwater sculpin at study sites around Lake Michigan, 1973-1980. $N D=$ no data. $N H=$ newly hatched, exact size not measured.

\begin{tabular}{|c|c|c|c|c|c|c|}
\hline \multirow[b]{2}{*}{ Site } & \multicolumn{3}{|c|}{ Entrainment and field occurrences } & \multicolumn{3}{|c|}{ Field occurrences } \\
\hline & $\begin{array}{c}\text { First-last } \\
\text { collection } \\
\text { dates }\end{array}$ & $\begin{array}{l}\text { Larva } \\
\text { total length } \\
(\mathrm{mm})\end{array}$ & $\begin{array}{c}\text { Water } \\
\text { temperature } \\
\text { (C) }\end{array}$ & $\begin{array}{c}\text { Station } \\
\text { (bottom } \\
\text { contour, } \mathrm{m} \text { ) }\end{array}$ & $\begin{array}{l}\text { Depth } \\
\text { stratum } \\
\text { (m) }\end{array}$ & $\begin{array}{c}\text { Density } \\
\text { (number per } \\
1,000 \mathrm{~m}^{3} \text { ) }\end{array}$ \\
\hline \multicolumn{7}{|c|}{ Burbot } \\
\hline \multicolumn{7}{|l|}{ East shore } \\
\hline Cook & 29 Mar-12 Jun & $3.5-6.0$ & $0-15$ & $1-21$ & $0-13.5$ & $30-512$ \\
\hline Palisades & 15 Apr-15 May & $3.4-4.6$ & ND & $3-15$ & ND & $<10$ \\
\hline Campbell & 11 Арг-19 Jun & $3.0-7.5$ & $4-19$ & $1-15$ & $0-12$ & $12-843$ \\
\hline Ludington & 17 Apr-29 Jun & $3.1-4.4$ & $3-16$ & $1.5-12$ & ND & $2-120$ \\
\hline \multicolumn{7}{|l|}{ West shore } \\
\hline Ozaukee ${ }^{\mathrm{a}}$ & $10 \mathrm{May}-18 \mathrm{May}$ & NH & $6-7$ & 6 & 6 & $20-29$ \\
\hline Haven & $16 \mathrm{May}-5$ Jun & NH & $6-8$ & $3-12$ & $0-11$ & $16-61$ \\
\hline Escanaba & $27 \mathrm{Apr}-14 \mathrm{Jun}$ & $3.5-7.0$ & $1-15$ & $1.5-9$ & ND & $9-24,000$ \\
\hline \multicolumn{7}{|c|}{ Deepwater sculpin } \\
\hline \multicolumn{7}{|l|}{ East shore } \\
\hline Cook $^{\mathrm{a}}$ & $30 \mathrm{Mar}-8 \mathrm{May}$ & $9-12.8$ & $0-11$ & 9 & 8 & $27-65$ \\
\hline Palisades & $28 \mathrm{Apr}-4 \mathrm{Aug}$ & $9-21$ & ND & $3-15$ & ND & $<10$ \\
\hline Campbell & $2 \mathrm{Feb}-18 \mathrm{Aug}$ & $8-18.3$ & $2-10$ & 6-18 & $2.5-17$ & $11-71$ \\
\hline Ludington & 15 Apr-15 Aug & $8.9-22$ & $3-10$ & $1.5-12$ & ND & $3-57$ \\
\hline \multicolumn{7}{|l|}{ West shore } \\
\hline Ozaukee & 11 Apr-10 May & $8.5-13$ & $2-6$ & $6-12$ & $0-12$ & $5-78$ \\
\hline Haven $^{\mathrm{a}}$ & 4 Apr-11 Jul & $8.5-13$ & $3-7$ & $9-12$ & $4-11$ & $22-24$ \\
\hline Escanaba & None & & & & & \\
\hline
\end{tabular}

${ }^{a}$ Few occurrences only.

identification of specimens. Many larvae from Campbell, Cook, Escanaba, and Haven were compared with those in the Great Lakes Regional Fish Larvae Collection (Dorr and Jude 1981) to verify identification.

Length-frequency distributions of larvae collected during day and night from Campbell were compared for diel differences by the nonparametric Smirnov test (Conover 1971). This analysis permitted assessment of net avoidance by larvae relative to their size. Attained significance $(P)$ was computed according to Birnbaum and Hall (1960).

\section{Results \\ Burbot}

Earliest collections of burbot larvae were on 29 March (Table 2), in Cook Plant entrainment samples. Thus, field sampling that began in April covered peak abundances that, in most years, occurred from late April through May. In 1978, when all sites were sampled, the period of peak abundance occurred 2-4 weeks earlier at southerly than at northerly sites. Most burbot larvae collected were newly hatched, 3.4$5.0 \mathrm{~mm}$ TL (see Fig. 2 for an example; see also
Jude 1982 for a summary of sizes at hatch). A few larger larvae (up to $7.5 \mathrm{~mm}$ ) were collected, but usually about a month after the first appearance of small burbot larvae. No burbot larvae were collected after June.

Burbot larvae were collected from waters of 0-19 C, but over $90 \%$ were taken at temperatures less than $12 \mathrm{C}$. Greatest larva densities occurred at 6-11 C, particularly at Escanaba and Campbell.

At sites where burbot larvae were common, they were found at all stations sampled. However, during April and May at eastern Lake Michigan sites, their densities were often up to an order of magnitude higher at 1 -m stations than at deeper ones. Densities at eastern locations reached $843 / 1,000 \mathrm{~m}^{3}$ at the 1 -m Campbell station (May 1980), but never exceeded 150 larvae $/ 1,000 \mathrm{~m}^{3}$ at stations beyond the $3-\mathrm{m}$ contour. During June, larvae were more evenly distributed among various stations.

Along the western shore, burbot larvae seemed less concentrated at shallow stations. At Haven, they were evenly distributed among 3to 12-m stations (the 1-m contour was not sampled), but not abundantly. At Ozaukee, a few 


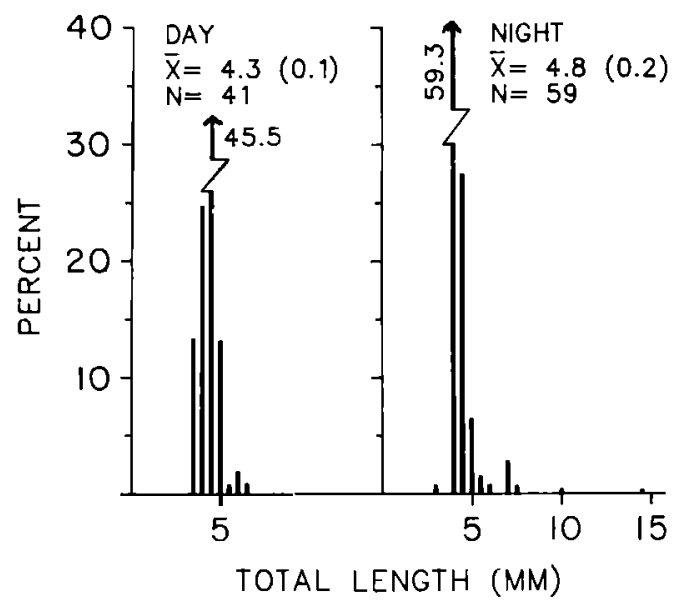

F1Gure 2.-Length-frequency histograms for burbot larvae collected during day and night at the J. H. Campbell Plant, eastern Lake Michigan, April to June 1977-1980. $\overline{\mathrm{X}}=$ mean total length, $\mathrm{N}=$ total number of larvae. Standard errors are in parentheses.

were encountered at the 6-m, but not the 9- or 12-m stations; shallower areas were not sampled. The highest densities found anywhere occurred in northern Green Bay near Escanaba.
For all transects combined, densities were highest inshore at time of peak hatch, as at eastern sites, but at other times, differences among stations were neither great nor consistent (Fig. 3). Even at peak abundance, inshore clustering of larvae was apparent only for the southern two transects, which were both closest to the Bark River and had the steepest bottom slope (Fig. 4). During all sampling periods fewer larvae were collected along the two shoal transects than along the three southern ones, but densities on the shoal still were generally higher than those found at any other site.

At Cook, Campbell, Haven, and Ozaukee, where sampling was conducted at discrete depth strata, burbot larvae were distributed evenly among strata from the surface to the bottom at depth contours less than $9 \mathrm{~m}$. Burbot larvae were collected no deeper than the $13.5-\mathrm{m}$ stratum. Although vertical-distribution data were pooled at Escanaba, our field impressions were that no marked differences occurred among strata except on 10 May, when most larvae were near the bottom. These larvae probably were sampled while hatching and had not yet risen from the bottom. In general, there was no ob-

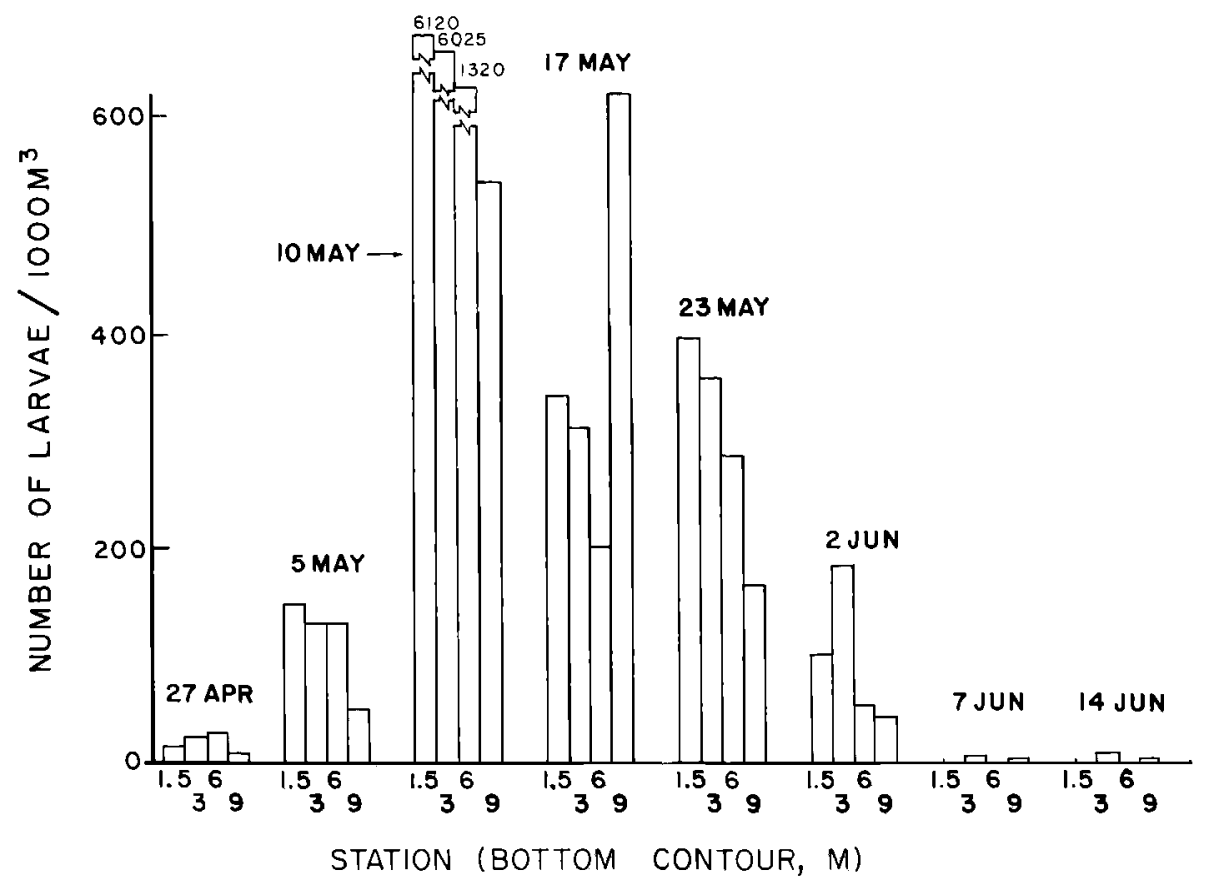

Figure 3.-Densities of burbot larvae at or above four bottom contours near Escanaba, Michigan, 27 April-14 June 1978. Data from all transects are pooled. 


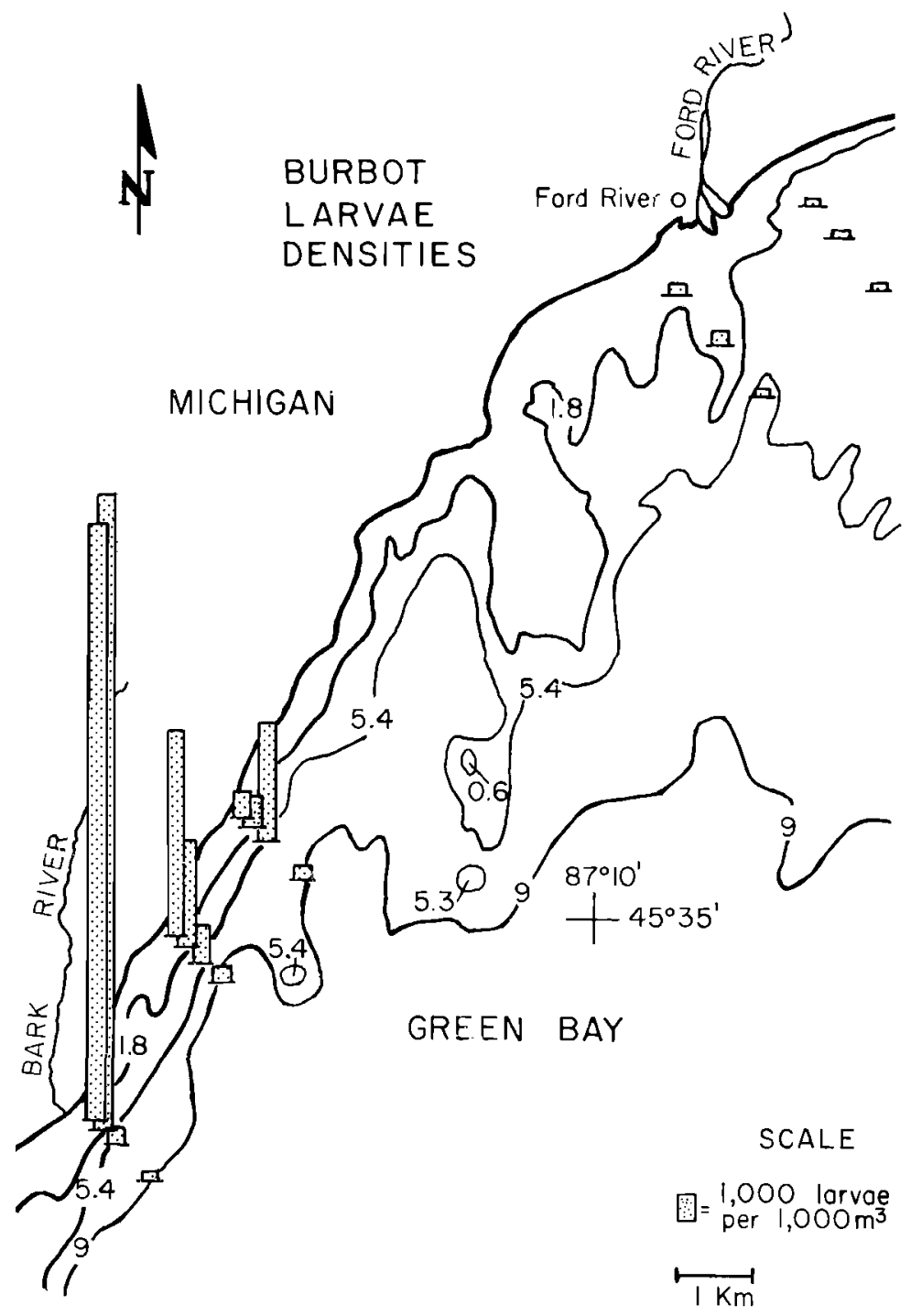

FigurE 4.-Densities of burbot larvae at 18 sampling stations near Escanaba, Michigan, 10 May 1978. Bottom contours are shown in meters.

vious pattern in size distribution of larvae among depth strata sampled.

At sites where sampling was conducted day and night, slightly more burbot larvae were caught at night. Length-frequency distributions compared by the Smirnov test were not significantly different $(P=0.68)$ between day and night, but larvae longer than $6.5 \mathrm{~mm}$ were only collected at night at the Campbell site (Fig. 2), suggesting larger larvae could avoid plankton nets during daytime.

\section{Deepwater Sculpin}

Earliest collections of deepwater sculpin larvae were on 2 February (Table 2) in Campbell entrainment samples. Year-round entrainment sampling at Campbell and Cook indicated greatest abundance was from early March to early May. Individuals were encountered as late as mid-August at Campbell and Ludington. Summer collections were either from stations lakeward of the 15-m contour or coincided with 


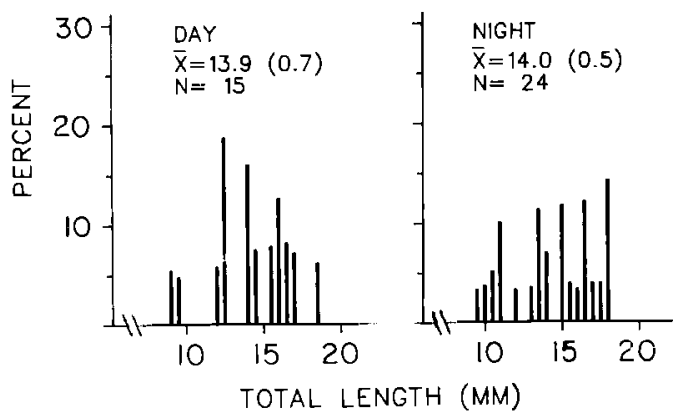

FIGURE 5.-Length-frequency histograms for deepwater sculpin larvae collected during day and night at the J. H. Campbell Plant, eastern Lake Michigan, February to August 1977-1980. $\overline{\mathrm{X}}=$ mean total length, $\mathrm{N}=$ total number of larvae. Standard errors are in parentheses.

upwellings of cold water. The warmest water temperature at which deepwater sculpin larvae were collected was $11 \mathrm{C}$.

Most deepwater sculpin larvae collected were 9-18 mm TL as exemplified by Campbell data (Fig. 5). Even the smallest larva $(8.0 \mathrm{~mm})$ had little yolk present and may not have been newly hatched. (Length at hatch has not been reported for this species.) Larger larvae, 18-22 mm, occurred from April through August at Campbell and Ludington.

Unlike adults, deepwater sculpin larvae were not bottom-oriented, but occurred regularly in surface and midwater samples; they were not abundant at any site (Table 2). There was no pattern of abundance with depth contour for most sites (aside from scarcity at stations less than $6 \mathrm{~m}$ ), except at Ludington, where there was a tendency toward greater abundance at deeper stations.

More deepwater sculpin larvae were collected at night (79\% at Ludington and $62 \%$ at Campbell) than during the day, but length-frequency distributions of Campbell larvae (Fig. 5) were not significantly different by diel period $(P=$ 1.00) when compared by the Smirnov test. No deepwater sculpin larvae were collected at Escanaba.

\section{Discussion \\ Burbot}

Burbot egg incubation lasts about 70 days at 0 to 1.5 C (McCrimmon 1959; Muth 1973), but hatching is triggered if water temperature rises only slightly; for example, hatching begins after
46 days if the water is warmed 2-3 degrees (Muth 1973). This hinders an accurate inference of spawning times from times of peak abundance of larvae. Burbot are known to spawn under the ice in midwinter (Fabricius 1954; Scott and Crossman 1973; Jude et al. 1979; Coberly and Horrall 1980). Larval-fish data from eastern Lake Michigan imply possible spawning from late December through late April. However, a spawning period extending into April is unlikely because no adult burbot in spawning condition have been collected during that month (Brazo and Liston 1979; Jude et al. 1979, 1981). Burbot with ripe gonads were collected during January and December 1974 at Cook, and burbot eggs were found in tows at the 1-m contour in January 1974 (Jude et al. 1979). At the northernmost site (Escanaba) water warmed very gradually through mid-May, suggesting that $3.5-104.5-\mathrm{mm}$ larvae collected in June may have been spawned in March or early April.

The Atlantic tomcod Microgadus tomcod is the only other member of the family Gadidae to enter North American freshwater streams (Scott and Crossman 1973), which it does from October to December. Atlantic tomcod spawn along shore, in stream mouths or in creeks over sand or gravel, usually associated with ice (Hardy 1978). Our data and other studies (Adams and Hankinson 1928; Coberly and Horrall 1980) suggest similar spawning behavior by burbot, with the addition of reef-spawning in Green Bay.

Absence of burbot longer than $8 \mathrm{~mm}$, and infrequent occurrence of burbot larvae 5.5-7.5 $\mathrm{mm}$, in samples could be due to mortality, dispersal, or net avoidance, most likely a combination of the three. The high fecundity of burbot, sometimes over 1 million eggs per female (Muth 1973), suggests that high mortality occurs early in life (Everhart et al. 1975). Net avoidance by larvae usually increases with size. Young-of-the-year burbot seldom were observed during late summer or fall in the inshore waters of Lake Michigan. A few young of the year were impinged at the Cook Plant (Great Lakes Research Division, unpublished data), and burbot 200-230 $\mathrm{mm}$ TL (young of the year or yearlings) were collected during October in the Grand River, Grand Haven, Michigan (C. Pistis, Michigan Sea Grant Marine Advisory Agent, personal communication). Burbot surviving past 
the larva period are believed to move to deeper waters $(>21 \mathrm{~m})$, based on our data and observations of Clady (1976) in Oneida Lake, New York. Similarly, Atlantic tomcod larvae in the St. Lawrence estuary are most abundant upstream when newly hatched, then move downstream to deeper waters and become more demersal (Able 1978).

The wide range of water temperatures $(0-$ 19 C) at which burbot larvae were collected may indicate varying environmental conditions near shore in Lake Michigan rather than temperature preference. Burbot larvae of the size normally captured $(3.5-5.5 \mathrm{~mm})$ have little fin development. Thus, larvae are vulnerable to currents and may not be able to avoid less preferred temperatures. Higher densities at cooler temperatures suggest most hatching occurs before inshore waters of Lake Michigan exceed 8-10 C. Larval burbot probably are best adapted to cool waters, as are adults. This is inferred from our data and their distribution in cool northern climates.

High densities of burbot larvae within the 3$m$ bottom contour, especially at Escanaba, indicate spawning may have occurred near shore. Although burbot eggs are semi-buoyant when first spawned, after a few days they become demersal (Fabricius 1954). Distribution of burbot larvae at moderate densities throughout the water column in nearshore Lake Michigan demonstrates passive dispersal by currents shortly after hatching, because larvae are more buoyant than their eggs.

Ozaukee produced the fewest burbot, but depth contours less than $6 \mathrm{~m}$ were not sampled. Ozaukee has a featureless sand bottom, whereas Haven has a rocky bottom and yielded more burbot larvae at 6 - to 12-m stations. Rocky sites appear to be preferred when available. Densities of larvae at Escanaba were greatest over rocky substrate; however, rocky substrate coincided with proximity to the Bark River. Adult burbot have been observed in the Bark and Ford Rivers in late winter, but no sampling was conducted in the rivers. Spawning may occur in rivers, larvae subsequently drif ting downstream to the lake. Postspawning migrations upriver by adult burbot, possibly to feed, have been reported in Canada (McCrimmon and Devitt 1954; Scott and Crossman 1973). Rivers may serve as sources of food for young burbot, making spawning near river mouths advantageous.
A Wyoming study (Bjorn 1940) showed that burbot migrated $0.9 \mathrm{~km}$ upriver to spawn in a creek bed. Burbot inhabiting a portion of the Tanana River, Alaska, spawn in its tributary, the Chena River (Chen 1969). At the Campbell site, power-plant-impingement sampling indicated burbot moved into Pigeon Lake (location of the plant intake), adjacent to Lake Michigan, during winter. They apparently spawned in Pigeon Lake or upstream in Pigeon River, demonstrated by subsequent entrainment and nearshore distribution of larvae (Jude et al. 1980). Adult burbot also have been collected during winter in Muskegon Lake, which connects the Muskegon River and Lake Michigan, and the St. Joseph River as far upstream as Berrien Springs (C. Pistis, Sea Grant Marine Advisory Agent, personal communication). Thus, various tributaries of Lake Michigan serve as important spawning sites or nursery areas for burbot.

Many burbot in Lake Michigan probably are spawned in Green Bay, as shown by both Escanaba larval-fish data and commercial catch records. Ripe burbot frequently are gillnetted through the ice in January and February over shoals and reefs or near shore in Green Bay, and are encountered most frequently in the northern part of the bay (Coberly and Horrall 1980; T. A. Edsall, Great Lakes Fishery Laboratory, personal communication). The many streams flowing into Green Bay may provide spawning habitat for burbot, in addition to reefs and nearshore areas.

\section{Deepwater Sculpin}

We collected very few adult deepwater sculpin at our sites (Jude et al. 1981; Liston et al. 1981; Great Lakes Research Division, unpublished data). Adults primarily inhabit waters deeper than $50 \mathrm{~m}$ in Lake Michigan (Deason 1939; Wells 1968), so our transects, to $21 \mathrm{~m}$, reached only the fringes of the population. Wells (1968) found that during October, November, February, and March, deepwater sculpin had no more shallow a distribution than during summer, so important inshore spawning migrations probably do not occur. More likely, spawning occurs at depths greater than $21 \mathrm{~m}$ and larvae subsequently disperse, some appearing inshore.

Westin (1969) found egg incubation of fourhorn sculpin lasted 97 days at 1.5 C. If deep- 
water sculpin have a similar incubation period (not yet demonstrated), the larvae that we collected (not newly hatched) from February to April would have been spawned from late October to January. Deepwater sculpin taken in November 1965-1975 in Lake Michigan, between depths of 73 and $110 \mathrm{~m}$, had cannibalized their own eggs (Wells 1980). Others collected from deep water during April also had consumed their own eggs; these were well developed, eyed, and therefore probably close to hatching (L. Wells, Great Lakes Fishery Laboratory, personal communication). Egg predation also is evidence for deepwater spawning, as well as for times of spawning and hatching.

The smallest deepwater sculpin larvae $(8 \mathrm{~mm})$ collected in our studies had already absorbed most of their yolk, so were not newly hatched. No smaller ones have been reported from previous studies (Heufelder 1982). Westin (1970) demonstrated that fourhorn sculpin males guard eggs in a nest during incubation. This also may be the case for deepwater sculpin, as it is a closely related species. Nest guarding would explain absence of newly hatched larvae in our tow samples, because guarded young remain near the nest, which is in deep water.

After absorbing their yolk, deepwater sculpin larvae become pelagic, as evidenced by their capture in all water strata, surface to bottom. Pelagic larvae are more exposed to currents than bottom dwellers and thus may be found far from spawning grounds. Relative abundance of deepwater sculpin larvae at Campbell and Ludington may be attributed to frequent upwellings at these sites along the central eastern shore. Using calcium concentrations, Ayers et al. (1958) distinguished bottom from surface water masses in Lake Michigan, and concluded that bottom currents frequently move from deep waters to the central eastern shore. Deepwater sculpin larvae, then, may be carried to the nearshore zone by upwellings. Current patterns could account for differences in larval-sculpin densities between Haven and Ozaukee as well. The western shore, however, does not display as consistent a current pattern as the eastern shore (Ayers et al. 1958).

\section{Acknowledgments}

This study was funded by the Environmental Department of Consumers Power Company, Jackson, Michigan; Wisconsin Electric Power Company, Milwaukee, Wisconsin; and Ameri- can Electric Power Service Corporation, Indiana and Michigan Electric Company. The manuscript was reviewed by Frank Tesar, Lee Fuiman, and George Heufelder. Jeffrey Braunscheidel and Dennis Mounsey drafted figures. Charles Madenjian assisted with statistics and provided computer-plotted figures. We thank LaRue Wells for his helpful comments, and the many people who assisted in collection and processing of data. This is contribution 354 of the Great Lakes Research Division, University of Michigan.

\section{References}

Able, K. W. 1978. Ichthyoplankton of the St. Lawrence estuary: composition, distribution, and abundance. Journal of the Fisheries Research Board of Canada 35:1518-1531.

Adams, C. C., and T. L. Hankinson. 1928. The ecology and economics of Oneida Lake fish. Roosevelt Wild Life Annals 1:235-548.

Ayers, J. C., D. C. Chandler, G. H. Lauff, C. F. Powers, and E. B. Henson. 1958. Currents and water masses of Lake Michigan. Great Lakes Research Institute, Publication 3, University of Michigan, Ann Arbor, Michigan, USA.

BAlley, M. M. 1972. Age, growth, reproduction and food of the burbot, Lota lota (Linnaeus), in southwestern Lake Superior. Transactions of the American Fisheries Society 101:667-674.

Birnbaum, Z. W., ANd R. A. Hall. 1960. Small sample distributions for multi-sample statistics of the Smirnov type. Annals of Mathematical Statistics 31:710-720.

BJorn, E. E. 1940. Preliminary observations and experimental study of the ling, Lota maculosa (LeSueur), in Wyoming. Transactions of the American Fisheries Society 69:192-196.

Brazo, D. C., and C. R. Lisron. 1979. The effects of five years of operation of the Ludington Pumped Storage Plant on the fishery resources of I ake Michigan. Department of Fisheries and Wildlife, Annual Report (1977) to Consumers Power Company, Ludington Project, Volume 2(1), Michigan State University, East Lansing, Michigan, USA.

Chen, L. 1969. The biology and taxonomy of the burbot, Lota lota leptura, in interior Alaska. Biological Papers of the University of Alaska 11.

Clady, M. D. 1976. Distribution atrd abundance of larval ciscoes, Coregonus artedii, and burbot, Lota lota, in Oneida Lake. Journal of Great Lakes Research 2:234-247.

Coberly, C. E., and R. M. Horrall. 1980. Fish spawning grounds in Wisconsin waters of the Great Lakes. University of Wisconsin Sea Grant Institute, WIS-SG-80-235, Madison, Wisconsin, USA.

Conover, N. J. 1971. Practical non-parametric sta- 
tistics. John Wiley and Sons, New York, New York, USA.

Deason, H. J. 1939. The distribution of cottid fishes in Lake Michigan. Papers of the Michigan Academy of Science, Arts and Letters 24:105-115.

Dork, J. A., III, AND D. J. Jude. 1981. Organization and status of a cooperative Great Lakes regional fish larvae collection. Journal of Greal Lakes Research 7:194-200.

Dorr, J. A., III, D. J. Jude, F. J. Tesar, And N. J. Thurber. 1976. Identification of larval fishes taken from the inshore waters of southeastern Lake Michigan near the Donald C. Cook Nuclear Plant, 1973-1975. United States Fish and Wildlife Service Biological Services Program FWS/ OBS-76/23:6I-82.

DRYER, W. R. 1966. Bathymetric distribution of fish in the Apostle Islands region, Lake Superior. Transactions of the American Fisheries Society 95:248-259.

Everhart, W. H., A. W. Eipper, Ano W. D. Youngs. 1975. Principles of fishery science. Cornell University Press, Ithaca, New York, USA.

Fabricius, E. 1954. Aquarium observations on the spawning behavior of the burbot, Lota vulgaris L. Institute of Freshwater Research Drottningholm Report 35:51-57.

Fish, M. P. 1932. Contributions to the early life hislories of sixty-two species of fishes from Lake Erie and its tributary waters. United States Bureau of Fisheries Bulletin 47:293-398.

Hardy, J. D., Jr. 1978. Development of fishes of the mid-Atlantic bight: an atlas of egg, larval and juvenile stages, volume II. United States Fish and Wildlife Service Biological Services Program FWS/ OBS-78/12.

Heufelder, G. R. 1982. Family Cottidae, sculpins. Pages 656-676 in N. A. Auer, editor. Identification of larval fishes of the Great Lakes basin with emphasis on the Lake Michigan drainage. Great Lakes Fishery Commission, Special Publication 82-3, Ann Arbor, Michigan, USA.

Jude, D. J. 1982. Family Gadidae, codfishes. Pages $470-476$ in N. A. Auer, editor. Identification of larval fishes of the Great Lakes basin with emphasis on the Lake Michigan drainage. Great Lakes Fishery Commission, Special Publication 82-3, Ann Arbor, Michigan, USA.

JUdE, D. J., AND SIx COAU'THORs. 1979. Inshore Iake Michigan fish populations near the D. C. Cook Nuclear Power Plant during preoperational years-1973, 1974. Great Lakes Research Division, Special Report 71, Universily of Michigan, Ann Arbor, Michigan, USA.

Jude, D. J., AND Eight COAuthors. 1980. Adult, juvenile and larval fish populations in the vicinity of the J. H. Campbell Power Plant, eastern Lake Michigan, 1979. Great Lakes Research Division, Special Report 79, University of Michigan, Ann Arbor, Michigan, USA

JUdF, D. J., AND Fight COAuThors. 1981. Adult, juvenile and larval fish populations in the vicinity of the J. H. Campbell Power Plant, eastern Lake Michigan, 1977-1980. Great Lakes Research Division, Special Report 86, University of Michigan, Ann Arbor, Michigan, USA.

KHAN, N. Y., AND D. J. FABER. 1974. A comparison of larvae of the deepwater and fourhorn sculpin, Myoxocephalus quadricornis L. from North America. I. Morphological development. Pages 703712 in J. H. S. Blaxter, editor. The early life history of fish. Springer-Verlag, New York, New York, USA.

LippSon, A. J., ANd R. L. MoRan. I974. Manual for identification of early developmental stages of fishes of the Potomac River estuary. Martin Marietta, Baltimore, Maryland, USA

Liston, C., D. Brazo, R. O'Neal, J. Bohr, G. PeterSON, AND R. Ligman. 1981. Assessment of larval, juvenile, and adult fish entrainment losses at the Ludington Pumped Storage Power Plant on Lake Michigan. Department of Fisheries and Wildlife, Annual Report (1980) to Consumers Power Company, Ludington Project, Volume I, Michigan State University, East Lansing, Michigan, USA.

McAllister, D. E., R. Murphy, and J. Morrison. 1978. The compleat minicomputer cataloging and research system for a museum. Curator 21 : 63-91.

MCCrimmon, H. R. 1959. Observations on spawning of burbot in Lake Simcoe, Ontario. Journal of Wildlife Management 23:447-449.

McCrimmon, H. R., and O. E. Dfvitt. 1954. Winter studies on the burbot, Lota lota lacustris, of Lake Simcoe, Ontario. Canadian Fish Culturist $16: 34-41$.

Muth, K. M. 1973. Population dynamics and life history of burbot, Lota lota (Linnaeus), in Lake of the Woods, Minnesota. Doctoral dissertation. University of Minnesota, Minneapolis, Minnesota, USA.

RoBins, G. R., AND SIX CoAurhors. 1980. A list of common and scientific names of fishes from the United States and Canada, 4th edition. American Fisheries Society Special Publication 12.

Scott, W. B., and E. J. Crossman. 1973. Freshwater fishes of Canada. Fisheries Research Board of Canada Bulletin 184.

SEgERSTRALE, S. G. 1970. Light control of the reproductive cycle of Pontoporeia affinis Lindström (Crustacea Amphipoda). Journal of Experimental Marine Biology and Ecology 5:272-275.

Van Oosten, J., R. Hile, and F. W. Jobes. 1946. The whitefish fishery of lakes Huron and Michigan with special reference to the deep-trap-net fishery. United States Fish and Wildlife Service Fishery Bulletin 50:297-394.

Wang, J. C. S., and R. J. Kernehan. 1979. Fishes of the Delaware estuaries: a guide to early life histories. Ecological Analysts Communications, Towson, Maryland, USA.

WAPORA. 1979. Aquatic survey of Lake Michigan near the Palisades Nuclear Plant. Part 4: ich- 
thyoplankton. Consumers Power Company, Jackson, Michigan, USA.

Wells, L. 1968. Seasonal depth distribution of fish in southeastern Lake Michigan. United States Fish and Wildlife Service Fishery Bulletin 67.

Wells, L. 1980. Food of alewives, yellow perch, spottail shiners, trout-perch, and slimy and fourhorn sculpins in southeastern Lake Michigan. United States Fish and Wildlife Service Technical Paper 98.

Wells, L., And A. L. McLain. 1972. Lake Michigan: effects of exploitation, introductions, and eutrophication on the salmonid community.
Journal of the Fisheries Research Board of Canada 29:889-898.

WhStin, L. 1969. The mode of fertilization, parental behavior and time of egg development in fourhorn sculpin, Myoxocephalus quadricornis (L.) Institute of Freshwater Research Drottningholm Report 49:175-182.

Westrin, L. 1970. The food ecology and the annual food cycle in the Baltic population of fourhorn sculpin, Myoxocephahes quadricornis (L.) Pisces. Institute of Freshwater Research Drottningholm Report 50:168-210. 